\title{
Substrate Specificities of the Soluble and Particulate Methane Mono-oxygenases of Methylosinus trichosporium OB3b
}

\author{
By KAREN J. BURROWS, ALEX CORNISH, ${ }^{*}$ DAVID SCOTT AND \\ I. JOHN HIGGINS \\ Biotechnology Centre, Cranfield Institute of Technology, Bedfordshire MK43 OAL, UK
}

(Received 23 July 1984; revised 10 September 1984)

\begin{abstract}
The intracellular location of methane mono-oxygenase (MMO) (soluble or particulate) in Methylosinus trichosporium OB3b is dependent on the availability of copper in the growth medium. Raising the $\mathrm{Cu}^{2+}$ concentration from $1 \mu \mathrm{M}$ to $5 \mu \mathrm{M}$ effected a transition from soluble to particulate MMO activity, and changes in major cell polypeptides were observed on SDSpolyacrylamide gels. Organisms containing soluble MMO oxidized a wide range of substrates including $n$-alkanes, $n$-alkenes, aromatic and alicyclic compounds. By contrast, organisms containing particulate MMO did not oxidize aromatic or alicyclic compounds. These observations provide further evidence that the two types of MMO are fundamentally different.
\end{abstract}

\section{INTRODUCTION}

The oxidation of methane to methanol by methanotrophs is catalysed by methane monooxygenase (MMO). Scott et al. (1981a,b) discovered that Methylosinus trichosporium OB3b possesses soluble or particulate (membrane-bound) cell-free MMO activity depending on the conditions under which it is grown. Particulate MMO was present in organisms grown in continuous culture under oxygen-limited, nitrate-excess conditions, whilst soluble MMO was present in nitrate-depleted cultures. It was suggested therefore, that the availability of nitrate might determine the intracellular location of MMO (Scott et al., 1981 a, b). Stanley et al. (1983) have now shown that in Methylococcus capsulatus (Bath) and $M$. trichosporium OB3b the intracellular location of MMO is determined by the availability of copper; particulate cell-free MMO activity was observed when the organisms were grown at high $\mathrm{Cu}^{2+}$ : biomass ratios, whereas organisms subjected to copper deficiency contained soluble MMO. The growth conditions used by Scott et al. (1981a) masked the underlying copper effect. The particulate and soluble MMOs were found to differ in inhibitor specificity, the former being more sensitive to metal-chelating agents, although $\mathrm{NAD}(\mathrm{P}) \mathrm{H}$ was found to be the only suitable electron donor for both activities (Scott et al., 1981a).

The ability of MMOs from a number of methanotrophs to oxidize a wide range of substrates is well documented (Colby et al., 1977; Stirling et al., 1979; Higgins et al., 1979; Patel et al., 1980). These substrates include $n$-alkanes, $n$-alkenes and ethers, and aromatic, alicyclic and heterocyclic compounds. Methylomonas methanica, however, appears to have a more restricted substrate range. The particulate cell-free MMO from this organism does not oxidize aromatic, alicyclic and heterocyclic compounds (Stirling et al., 1979).

This work compares directly the substrate specificities of $M$. trichosporium OB3b cells containing either soluble or particulate MMO.

\section{METHODS}

Organism and grow'th conditions. Methylosinus trichosporium $\mathrm{OB} 3 \mathrm{~b}$ was obtained from Professor R. Whittenbury, Department of Biological Sciences, University of Warwick, UK. The organism was grown on the nitrate mineral salts medium (NSM) of Cornish et al. (1984). This contains $1 \mu \mathrm{M}-\mathrm{Cu}^{2+}$ and is here referred to as the "low copper medium'. The 'high copper medium' referred to in the text contains $5 \mu \mathrm{M}-\mathrm{Cu}^{2+} . M$. trichosporium $\mathrm{OB} 3 \mathrm{~b}$ was grown 
on the low copper medium in continuous culture (oxygen-limited) in a 101 capacity LKB 1601 Ultroferm fermenter with methane as sole carbon source (temperature, $30{ }^{\circ} \mathrm{C}$; impeller speed, 500 r.p.m.; pH 6.8; methane flow rate, $250 \mathrm{ml} \mathrm{min}^{-1}$; air flow rate, $1000 \mathrm{ml} \mathrm{min}^{-1}$; dilution rate, $0.04 \mathrm{~h}^{-1}$; biomass density, $1.6-1.8 \mathrm{mg} \mathrm{dry} \mathrm{wt} \mathrm{ml}^{-1}$ ). The organism was grown on the high copper medium in continuous culture (oxygen-limited) in a 21 capacity fermenter (L. H. Engineering Co., type L.H.E. CC1500) with methane as sole carbon source (temperature, $30^{\circ} \mathrm{C}$; impeller speed, 400 r.p.m.; pH 6.8; methane flow rate, $50 \mathrm{ml} \mathrm{min}^{-1}$; air flow rate, $250 \mathrm{ml} \mathrm{min} \mathrm{m}^{-1}$; dilution rate, $0 \cdot 04 \mathrm{~h}^{-1}$ : biomass density, $1 \cdot 6-1 \cdot 8 \mathrm{mg}$ dry $\mathrm{wt} \mathrm{ml}^{-1}$ ).

Preparation of suspensions of $M$. trichosporium $O B 3 \mathrm{~b}$. Organisms were harvested by centrifugation $(4420 \mathrm{~g}$, $20 \mathrm{~min}, 4^{\circ} \mathrm{C}$ ), washed once with $20 \mathrm{~mm}$-sodium phosphate buffer containing $5 \mathrm{mM}-\mathrm{MgCl}_{2}(\mathrm{pH} 7 \cdot 0)$ and resuspended in the same buffer to give the required bacterial density (see below). Suspensions prepared in this way were used throughout this work.

Assay of cell-free MMO activity. Cell-free extracts were prepared from suspensions of $M$. trichosporium OB $3 \mathrm{~b}$ (30-35 $\left.\mathrm{mg} \mathrm{dry} \mathrm{wt} \mathrm{ml}^{-1}\right)$ using sonication to disrupt the cells $(4 \times 15 \mathrm{~s}$ bursts, $16 \mu \mathrm{m}$ amplitude, with $1 \mathrm{~min}$ cooling on ice between bursts). Particulate and soluble fractions were prepared and stored as described by Scott $e t$ al. (1981 a). MMO activity was measured by following the epoxidation of propene, a substrate of soluble and particulate MMO (Colby et al., 1977; Stirling et al., 1979; Scott et al., 1981 a). Assays were carried out in $10 \mathrm{ml}$ conical flasks (capped with Suba-seals) which contained $1 \mathrm{ml}$ soluble or particulate fractions (5-10 mg protein). Propene gas $(2 \mathrm{ml})$ was introduced by injection and the reaction was started by adding NADH $(5 \mathrm{~mm})$ as electron donor. Flasks were incubated at $30^{\circ} \mathrm{C}$ for $5 \mathrm{~min}$ in a reciprocating water bath shaker operating at 160 oscillations $\mathrm{min}^{-1}$. Propene oxide was measured by gas chromatography using a Porapak Q column $(2 \cdot 1 \mathrm{~m} \times 4 \mathrm{~mm}$ i.d.) attached to a Pye Unicam series 204 or 304 instrument fitted with flame ionization detectors [oven temperature, $140^{\circ} \mathrm{C}$; injector, $200^{\circ} \mathrm{C}$; detector, $200^{\circ} \mathrm{C}$; carrier gas $\left(\mathrm{N}_{2}\right)$ flow rate, $40 \mathrm{ml} \mathrm{min}^{-1}$ ].

Assay of whole-cell oxidations. Incubations were carried out in $10 \mathrm{ml}$ conical flasks (capped with Suba-seals) containing $1 \mathrm{ml}$ cell suspension (10-12 mg dry wt). Assays were started by injecting the substrate ( $2 \mathrm{ml}$ gaseous substrate, $2 \mu$ l liquid substrate). Sodium formate $(20 \mathrm{~mm})$ was used as a source of reducing equivalents in all assays. Flasks were shaken at $30^{\circ} \mathrm{C}$ in a reciprocating water bath operating at 160 oscillations min $^{-1}$. Samples were withdrawn for product determination $4 \mathrm{~min}$ after starting the incubation and thereafter at $10-12 \mathrm{~min}$ intervals over a period of $60 \mathrm{~min}$. Products were measured by gas chromatography using a Pye-Unicam series 204 or 304 instrument fitted with flame ionization detectors [detector, $200^{\circ} \mathrm{C}$; injector, $200^{\circ} \mathrm{C}$; carrier gas $\left(\mathrm{N}_{2}\right)$ flow rate, $40 \mathrm{ml} \mathrm{min}{ }^{-1}$ ]. Products of $n$-alkane oxidation (primary and secondary alcohols, and aldehydes) were analysed using a Porapak $\mathrm{Q}$ column $(2.1 \mathrm{~m} \times 4 \mathrm{~mm}$ i.d.). The column temperatures used for analysis of the oxidation products of different $n$-alkanes were as follows: ethane, $140^{\circ} \mathrm{C}$; propane, $180^{\circ} \mathrm{C}$; butane, $200^{\circ} \mathrm{C}$; pentane, $220^{\circ} \mathrm{C}$ and hexane, $220^{\circ} \mathrm{C}$. Products resulting from the oxidation of aromatic or alicyclic compounds were extracted into ethyl acetate $(1: 1, \mathrm{v} / \mathrm{v})$ and were then analysed using an SP2100 column $(2 \cdot 1 \mathrm{~m} \times 4 \mathrm{~mm}$ i.d. $)$. The column temperatures used to analyse oxidation products of aromatic and alicyclic substrates were as follows: benzene, $110^{\circ} \mathrm{C}$ ethylbenzene, $100^{\circ} \mathrm{C}$; styrene, $120^{\circ} \mathrm{C}$ and cyclohexane, $100^{\circ} \mathrm{C}$.

Ethanol disappearance was measured using gas chromatography. Reactions were carried out in $10 \mathrm{ml}$ conical flasks containing: cell suspension $\left(2 \cdot 5-10 \mathrm{mg}\right.$ dry $\left.\mathrm{wt} \mathrm{m}^{-1}\right), 1 \mathrm{ml}$; and ethanol $(15 \mathrm{mM})$. The flasks were capped with Suba-seals and shaken $\left(130\right.$ oscillations $\left.\mathrm{min}^{-1}\right)$ at $30^{\circ} \mathrm{C}$. Ethanol was determined as described above.

Dry weight determination. The dry weights of suspensions of $M$. trichosporium OB3b were determined by heating $1 \mathrm{ml}$ samples at $110^{\circ} \mathrm{C}$ to constant weight.

Protein determination. Protein content of cell-free extracts was determined using the modified Lowry assay of Peterson et al. (1977). Bovine serum albumin was used as a standard.

$S D S-P A G E$. Electrophoresis was carried out using $12 \%(\mathrm{w} / \mathrm{v})$ acrylamide gels using the discontinuous buffer system of Laemmli (1970). Proteins were fixed, stained with Coomassie blue and the gels destained as described by Laemmli (1970). The following were used as molecular weight standards : lactalbumin (mol. wt 14200); trypsin inhibitor, soybean (mol. wt 20100); trypsinogen, PMSF treated (mol. wt 24000); carbonic anhydrase from bovine erythrocytes (mol. wt 29000); glyceraldehyde-3-phosphate dehydrogenase, rabbit muscle (mol. wt 36000); albumin, egg (mol. wt 45000); albumin, bovine (mol. wt 66000). Methanol dehydrogenase of $M$. trichosporium OB3b (subunit mol. wt 60000) was used as a further standard. This was a gift from Dr D. J. Best, Cranfield Institute of Technology.

Chemicals. All chemicals were obtained from BDH except the molecular weight markers which were obtained from Sigma.

\section{RESULTS}

\section{Effect of copper ions on the intracellular location of $M M O$}

When M. trichosporium OB3b was grown on the low copper medium at biomass densities of $1.6-1.8 \mathrm{mg} \mathrm{dry} \mathrm{wt} \mathrm{ml}^{-1}$, the $\mathrm{MMO}$ activity was located predominantly in the soluble fraction of 


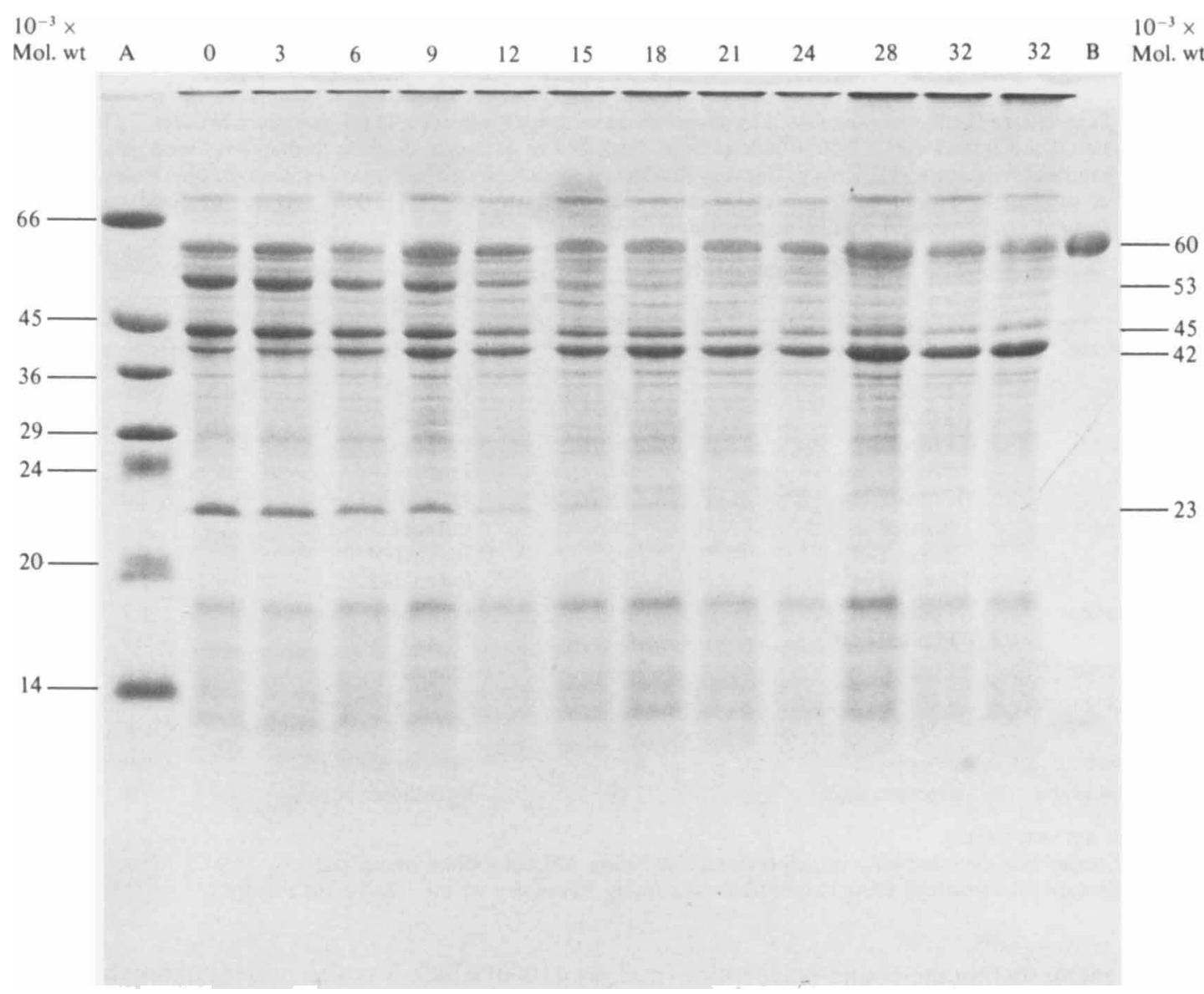

Fig. 1. SDS-PAGE of cell-free extracts from $M$. trichosporium $\mathrm{OB} 3 \mathrm{~b}$ during a switch from low to high copper medium. Cells were grown in continuous culture on low copper medium $\left(1 \mu \mathrm{M}-\mathrm{Cu}^{2+}\right.$; dilution rate, $0.04 \mathrm{~h}^{-1}$; biomass density, $1.6-1.8 \mathrm{~g}$ dry wt $\mathrm{l}^{-1}$ ). The concentration of $\mathrm{Cu}^{2+}$ was raised to $5 \mu \mathrm{M}$ by addition of $\mathrm{CuSO}_{4}$ solution to the chemostat and the feed was switched to high copper medium ( $5 \mu \mathrm{M}$ $\mathrm{Cu}^{2+}$ ). Samples were taken at intervals of 3-4 h for analysis of the cell-free extracts by SDS-PAGE. Electrophoresis was carried out as described in Methods. The numbers above each track indicate the time $(\mathrm{h})$ after the switch to high copper medium. Track A shows the molecular weight markers (mol. wt $66000,45000,36000,29000,24000,20100$ and 14200) and track B is purified methanol dehydrogenase from $M$. trichosporium OB3b (subunit mol. wt 60000).

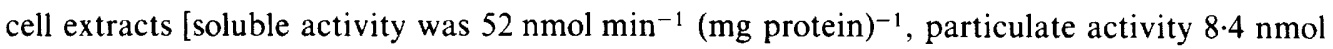
$\min ^{-1}$ (mg protein $)^{-1}$. By contrast, organisms grown on the high copper medium to the same biomass densities contained predominantly particulate MMO [soluble activity was $4.8 \mathrm{nmol}$ $\min ^{-1}$ (mg protein $)^{-1}$, particulate activity $62.5 \mathrm{nmol} \mathrm{min}^{-1}$ (mg protein $\left.)^{-1}\right]$. Organisms containing $100 \%$ particulate MMO were obtained by growing them on the high copper medium at a lower biomass density $\left(1 \cdot 0-1 \cdot 1 \mathrm{mg}\right.$ dry $\left.\mathrm{wt} \mathrm{ml}^{-1}\right)$; this was accomplished by increasing the dilution rate of the cultures from $0.04 \mathrm{~h}^{-1}$ to $0.043 \mathrm{~h}^{-1}$.

Differences in the amounts of major polypeptides were observed when the protein profiles of organisms containing either soluble or particulate MMO were analysed using SDS-PAGE. Three polypeptides (mol. wt 53000, 45000 and 23000) were present at high concentrations in the soluble fraction of organisms grown on the low copper medium (i.e those containing soluble MMO) (Fig. 1). All three polypeptides were virtually absent from soluble fractions of organisms grown on the high copper medium which contained particulate MMO. These contained instead 
Table 1. Oxidation of n-alkanes, and aromatic and alicyclic compounds by suspensions of $M$. trichosporium $O B 3 b$ containing either soluble or particulate $M M O$

Suspensions $(1 \mathrm{ml})$ were incubated in sealed flasks with each substrate $(2 \mathrm{ml}$ gaseous substrates, $2 \mu \mathrm{l}$ liquid substrates) over a time course $(1 \mathrm{~h})$ as described in Methods. Sodium formate was used as a source of reducing equivalents in all cases. Products were determined using gas chromatography. Rates

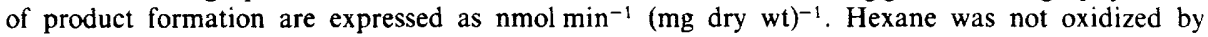
suspensions containing soluble or particulate MMO.

\begin{tabular}{|c|c|c|c|c|}
\hline \multirow[b]{2}{*}{ Substrate } & \multicolumn{2}{|c|}{ Soluble MMO } & \multicolumn{2}{|c|}{ Particulate $\mathrm{MMO}$} \\
\hline & Products detected & $\begin{array}{l}\text { Initial rate } \\
\text { of formation }\end{array}$ & Products detected & $\begin{array}{l}\text { Initial rate } \\
\text { of formation }\end{array}$ \\
\hline Ethane & Ethanol* & $\begin{array}{c}\text { ND } \\
25.0\end{array}$ & Ethanol* & $\begin{array}{l}\text { ND } \\
35 \cdot 0\end{array}$ \\
\hline Propane & $\begin{array}{l}\text { Propanal } \\
\text { Propan-1-ol } \\
\text { Propan-2-ol }\end{array}$ & $\begin{array}{r}3 \cdot 2 \\
6 \cdot 2 \\
4 \cdot 9\end{array}$ & $\begin{array}{l}\text { Propanal } \\
\text { Propan-1-ol } \\
\text { Propan-2-ol }\end{array}$ & $\begin{array}{r}2 \cdot 4 \\
0 \cdot 0 \\
12 \cdot 6\end{array}$ \\
\hline Butane & $\begin{array}{l}\text { Butanal } \\
\text { Butan-1-ol } \\
\text { Butan-2-ol }\end{array}$ & $\begin{array}{l}2 \cdot 6 \\
4 \cdot 2 \\
7 \cdot 3\end{array}$ & $\begin{array}{l}\text { Butanal } \\
\text { Butan-1-ol } \\
\text { Butan-2-ol }\end{array}$ & $\begin{array}{l}0 \cdot 6 \\
0 \cdot 0 \\
5 \cdot 9\end{array}$ \\
\hline Pentane & $\begin{array}{l}\text { Pentanal } \dagger \\
\text { Pentan-2-ol } \dagger\end{array}$ & $\begin{array}{l}1 \cdot 1 \\
0 \cdot 3\end{array}$ & $\begin{array}{l}\text { Pentanal } \dagger \\
\text { Pentan-2-ol } \dagger\end{array}$ & $\begin{array}{l}1 \cdot 1 \\
0 \cdot 5\end{array}$ \\
\hline Benzene & Phenol & $74 \cdot 0$ & Phenol & $0 \cdot 0$ \\
\hline Ethylbenzene & $\begin{array}{l}\text { 1-Phenylethanol } \\
\text { 4-Hydroxyethylbenzene }\end{array}$ & $\begin{array}{r}5 \cdot 7 \\
13 \cdot 0\end{array}$ & $\begin{array}{l}\text { 1-Phenylethanol } \\
\text { 4-Hydroxyethylbenzene }\end{array}$ & $\begin{array}{l}0 \cdot 0 \\
0 \cdot 0\end{array}$ \\
\hline Styrene & Styrene oxide & $82 \cdot 0$ & Styrene oxide & 0.0 \\
\hline Cyclohexane & Cyclohexanol & $25 \cdot 0$ & Cyclohexanol & $0 \cdot 0$ \\
\hline
\end{tabular}

one major membrane-bound polypeptide (mol. wt 42000) which was also present in organisms grown on the low copper medium, although in much lower amounts (Fig. 1).

Particulate MMO activity was lost when membranes prepared from organisms grown on the high copper medium were solubilised using Triton X-100 $(0.5 \%, \mathrm{v} / \mathrm{v})$ or sodium deoxycholate $(0.5 \%, \mathrm{w} / \mathrm{v})$.

\section{Substrate specificities of soluble and particulate $M M O$}

Oxidation of n-alkanes. Table 1 lists the products resulting from the oxidation of $n$-alkanes by suspensions of $M$. trichosporium $\mathrm{OB} 3 \mathrm{~b}$ which contained either soluble or particulate $\mathrm{MMO}$, and gives the initial rates of their formation. The figures given for primary alcohols cannot be regarded as true rates, since these are oxidized further to the corresponding aldehydes by the nonspecific methanol (primary alcohol) dehydrogenase (Patel et al., 1972). The aldehydes may also be oxidized further by a general aldehyde dehydrogenase to give the corresponding carboxylic acids (Patel et al., 1980). Suspensions containing either soluble or particulate MMO oxidized ethane to acetaldehyde without accumulating ethanol. Formation of ethanol was observed, however, when suspensions were prepared in 200 mM-sodium phosphate buffer, showing that ethanol is the initial oxidation product. The accumulation of ethanol under these circumstances is due to inhibition of the methanol oxidation by high concentrations of phosphate (Higgins \& Quayle, 1970), though there is no evidence that this is due to direct inhibition of methanol dehydrogenase. On raising the phosphate concentration from $20 \mathrm{~mm}$ to $200 \mathrm{~mm}$ there was a $91 \%$ decrease in the rate of ethanol oxidation by organisms containing particulate MMO, whilst MMO activity, measured by following the epoxidation of propene in the presence of $20 \mathrm{~mm}$ sodium formate, decreased by only $25-30 \%$. Suspensions of $M$. trichosporium OB3b containing soluble MMO catalysed both terminal and subterminal hydroxylation of propane and butane, as evidenced by the formation of the corresponding primary and secondary alcohols. Suspensions 


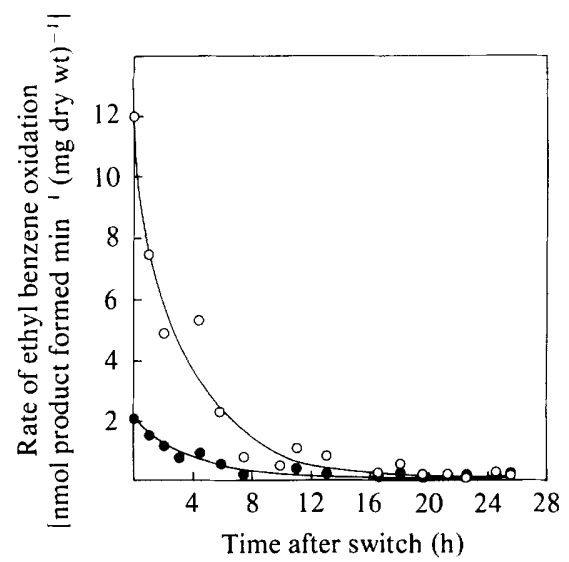

Fig. 2. Oxidation of ethyl benzene by $M$. trichosporium OB3b during a switch from low to high copper medium. Cells were grown in continuous culture on low copper medium $\left(1 \mu \mathrm{M}-\mathrm{Cu}^{2+}\right.$; dilution rate, $0.04 \mathrm{~h}^{-1}$; biomass density, $1.6-1.8 \mathrm{~g}$ dry wt $\mathrm{l}^{-1}$ ). The concentration of $\mathrm{Cu}^{2+}$ was raised to $10 \mu \mathrm{M}$ by addition of $\mathrm{CuSO}_{4}$ solution to the chemostat and the feed was switched to high copper medium $(10 \mu \mathrm{M}$ $\left.\mathrm{Cu}^{2+}\right)$. Samples $(10 \mathrm{ml})$ were taken at intervals for determination of whole cell ethyl benzene oxidation rates. Organisms were incubated with shaking at $30^{\circ} \mathrm{C}$ in $250 \mathrm{ml}$ conical flasks in the presence of ethyl benzene $(10 \mu \mathrm{l})$ and sodium formate $(20 \mathrm{~mm})$ as a source of reducing equivalents. Products, 4-hydroxethylbenzene $(O)$ and 1-phenylethanol $(O)$, were analysed as described in Methods.

containing particulate MMO oxidized propane and butane to the corresponding secondary alcohols, but primary alcohols were not detected. Propanal and butanal accumulated, however, showing that terminal hydroxylation was occurring but that both the respective primary alcohols were oxidized further. Both MMOs oxidized pentane to pentanal (via pentan-1-ol) and pentan-2-ol, but oxidation at position 3 of the carbon chain was not observed. Oxidation products were not detected when suspensions or cell-free extracts were incubated with $n$-hexane. This was true whether they contained soluble or particulate MMO.

\section{Oxidation of aromatic and alicyclic compounds}

Organisms containing soluble MMO oxidized benzene, ethylbenzene, styrene and cyclohexane, yielding the products listed in Table 1. By contrast, none of these compounds were oxidised by organisms which contained only the particulate enzyme. This suggests that the two MMOs differ significantly in their capacity to hydroxylate cyclic hydrocarbons. Cultures grown on the low copper medium progressively lost the capacity to oxidize ethylbenzene when the concentration of cupric ions was raised from $1 \mu \mathrm{M}$ to $10 \mu \mathrm{M}$ (Fig. 2), yet their ability to oxidize propene remained constant $\left[150-160 \mathrm{nmol} \mathrm{min}^{-1}(\mathrm{mg} \text { dry wt })^{-1}\right]$. These observations confirmed that the copper-induced transition from soluble to particulate MMO is accompanied by the loss of the ability to hydroxylate aromatic substrates. When the copper concentration of the fermenter feedstock was returned to $1 \mu \mathrm{M}$, the organism regained the ability to oxidize ethylbenzene (not shown).

\section{DISCUSSION}

This work corroborates the finding of Stanley et al. (1983) that copper availability determines the intracellular location (soluble or particulate) of $\mathrm{MMO}$ in $M$. trichosporium OB3b. This is also the case for Methylococcus capsulatus (Bath) (Stanley et al., 1983). Research to date (Scott et al., $1981 a$; Stanley et al., 1983) has indicated that there are differences between soluble and particulate MMOs besides their intracellular location, which suggest that the particulate enzymes are not derived from the soluble enzymes merely by membrane attachment. Our results support and extend previous findings.

In both $M$. trichosporium OB3b and $M$. capsulatus (Bath) the inhibitor profile of the soluble MMOs differs considerably from that of the particulate enzyme (Scott et al., 1981 a; Stanley et 
al., 1983), and although both types of MMO can use NADH as an electron donor in vitro, Tonge et al. (1975) have suggested that in vivo the particulate enzymes may receive reducing equivalents from the electron transport chain or from NADH-independent dehydrogenases such as methanol dehydrogenase. This is supported by the recent observations of Leak \& Dalton, (1983). Our findings show that the particulate $\mathrm{MMO}$ of $\boldsymbol{M}$. trichosporium $\mathrm{OB} 3 \mathrm{~b}$ differs from the soluble enzyme in that it is unable to oxidize aromatic or alicyclic compounds (both enzymes oxidize methane, propene and $n$-alkanes). This suggests that the hydroxylase components of the two enzymes are different, and provides a further important distinction between the two types of MMO. It is of interest to note that the substrate specificity of the particulate MMO of Methylomonas methanica (Stirling et al., 1979) is the same as that reported here for the corresponding enzyme from $M$. trichosporium OB3b. The ability to oxidize $n$-alkanes and $n$-alkenes but not aromatics or alicyclics may prove to be a general property of particulate MMOs, in which case it might be possible to determine whether or not organisms possess the soluble enzyme (which oxidize all four classes of compound) simply by measuring their capacity to oxidize a cyclic hydrocarbon such as ethylbenzene. This is clearly possible for $M$. trichosporium OB3b.

It has been suggested that methanotrophs might be used as biocatalysts in order to carry out epoxidations and hydroxylations on an industrial scale (Higgins et al., 1981; Whittenbury \& Dalton, 1982; Hou, 1984). Our findings shown that if $M$. trichosporium OB3b is to be used to oxidize cyclic hydrocarbons in an industrial process, then it will be essential to ensure that it is grown under conditions which yield soluble MMO. This restriction may well apply to other methanotrophs.

The soluble MMO of $M$. capsulatus (Bath) is now known to be a three-component enzyme (Colby \& Dalton, 1976; Woodland \& Dalton, 1984), and the corresponding enzyme from M. trichosporium OB3b seems to be essentially similar (Stirling \& Dalton, 1979). By contrast, nothing is known of the polypeptide composition of the respective particulate enzymes. Stanley et al. (1983) have shown that three major polypeptides are present in cell-free extracts prepared from suspensions of $M$. capsulatus (Bath) which contain soluble MMO. These correspond to the three subunits (mol. wt 54000, 42000, 17000) of component A of the soluble MMO of this organism, and may constitute up to $30 \%$ of the total soluble protein (Woodland \& Dalton, 1984). All three polypeptides disappear during the copper-induced transition from soluble to particulate MMO, whilst additional membrane-bound polypeptides accumulate (Stanley et al., 1983). The levels of some of the major cellular polypeptides of $M$. trichosporium $\mathrm{OB} 3 \mathrm{~b}$ appear to change in a similar fashion, although it is not known at present whether any of these correspond to components of the soluble or particulate MMOs. This will only be established when both enzymes from $M$. trichosporium $\mathrm{OB} 3 \mathrm{~b}$ have been purified, and this is currently under investigation. This is likely to prove difficult for the membrane-bound enzyme, however, since attempts to solubilize the particulate MMOs of both $M$. methanica (Colby et al., 1975) and $M$. trichosporium OB3b (the present work) have resulted in loss of activity.

We wish to thank the Science and Engineering Research Council for funding (K. J. B. \& A. C.) and Pfizer Ltd, Sandwich, for a CASE award (K. J. B.). We also thank Dr J. A. Bolbot for helpful discussions during the preparation of this manuscript.

\section{REFERENCES}

Colby, J. \& Dalton, H. (1976). Some properties of a soluble methane mono-oxygenase from Methylococcus capsulatus strain Bath. Biochemical Journal 157, 495-497.

Colby, J., Dalton, H. \& Whittenbury, R. (1975). An improved assay for bacterial methane mono-oxygenase: some properties of the enzyme from Methylomonas methanica. Biochemical Journal 151, 459-462.

Colby, J., Stirling, D. I. \& Dalton, H. (1977). The soluble methane mono-oxygenase of Methylococcus capsulatus (Bath). Its ability to oxygenate $n$-alkanes, $n$-alkenes, ethers and alicyclic, aromatic and heterocyclic compounds. Biochemical Journal 165, 395-402. Cornish, A., Nicholls, K. M., SCott, D., Hunter, B. K., Aston, W. J., Higgins, I. J. \& SAnders, J. K. M. (1984). In vivo ${ }^{13} \mathrm{C}-\mathrm{NMR}$ investigations of methanol oxidation by the obligate methanotroph, Methylosinus trichosporium OB3b. Journal of General Microbiology 130, 2565-2575.

Higgins, I. J., Best, D. J., Hammond, R. C. \& Scott, D. (1981). Methane-oxidizing microorganisms. Microbiological Review's 45, 556-590. 
Higgins, I. J. \& Quayle, J. R. (1970). Oxygenation of methane by methane-grown Pseudomonas methanica and Methanomonas methanooxidans. Biochemical Journal 118, 201-208.

Higgins, I. J., Hammond, R. C., Sariaslani, F. S., Best, D. J., Davies, M. M., Tryhorn, S. E. \& TAYLOR, F. (1979). Biotransformation of hydrocarbons and related compounds by whole organism suspensions of methane-grown Methylosinus trichosporium $\mathrm{OB} 3 \mathrm{~b}$. Biochemical and Biophysical Research Communications 89(2), 671-677.

Hou, C. T. (1984). Propylene oxide production from propylene by immobilised whole cells of Methylosinus sp. CRL 31 in a gas-solid bioreactor. Applied Microbiology and Biotechnology 19, 1-4.

LAEMMLI, U. K. (1970). Cleavage of structural proteins during the assembly of the head of bacteriophage T4. Nature, London 277, 680-685.

LEAK, D. J. \& DaltoN, H. (1983). In vivo studies of primary alcohols, aldehydes and carboxylic acids as electron donors for the methane mono-oxygenase in a variety of methanotrophs. Journal of General Microbiology 129, 3487-3497.

Patel, R. N., Bose, H. R., Mandy, W. J. \& Hoare, D. S. (1972). Physiological studies of methane- and methanol-oxidizing bacteria: comparison of a primary alcohol dehydrogenase from Methylococcus capsulatus (Texas strain) and Pseudomonas species M27. Journal of Bacteriology 110(2), 570-577.

Patel, R. N., Hou, C. T., Derelenko, P. \& Felix, A. (1980). Purification and properties of a hemecontaining aldehyde dehydrogenase from Methylosinus trichosporium. Archives of Biochemistry and Biophysics 203(2), 654-662.

Peterson, G. L. (1977). A simplification of the protein assay of Lowry et al. which is more generally applicable. Analytical Biochemistry 83, 346-356.

ScotT, D., Brannan, J. \& Higgins, I. J. (1981 $a$ ). The effect of growth conditions on intracytoplasmic membranes and methane mono-oxygenase activities in Methylosinus trichosporium OB3b. Journal of General Microbiology 125, 63-72.

Scott, D., Best, D. J. \& Higgins, I. J. (198!b). Intracytoplasmic membranes in oxygen-limited chemostat cultures of Methylosinus trichosporium OB3b: biocatalytic implications of physiologically balanced growth. Biotechnology Letters 3, 641-644.

Stanley, S. H., Prior, S. D., Leak, D. J. \& Dalton, H. (1983). Copper stress underlies the fundamental change in intracellular location of methane monooxygenase in methane-oxidising micro-organisms: Studies in batch and continuous culture. Biotechnology Letters 5, 487-492.

Stirling, D. I., Colby, J. \& Dalton, H. (1979). A comparison of the substrate and electron-donor specificities of the methane mono-oxygenases from three strains of methane-oxidising bacteria. Biochemical Journal 177, 361-364.

StiRling, D. I. \& Dalton, H. (1979). Properties of the methane mono-oxygenase from extracts of Methylosinus trichosporium $\mathrm{OB} 3 \mathrm{~b}$ and evidence for its similarity to the enzyme from Methylococcus capsulatus (Bath). European Journal of Biochemistry 96, 205212.

Tonge, G. M., Harrison, D. E. F., Knowles, C. J. \& Higgins, I. J. (1975). Properties and partial purification of the methane oxidising enzyme system from Methylosinus trichosporium. FEBS Letters 58(1), 293-299.

Whittenbury, R. \& Dalton, H. (1982). The obligate methane-oxidizing bacteria and their biotechnological potential. Basic Life Sciences 25, 439460.

Woodland, M. P. \& Dalton, H. (1984). Purification and characterization of component $\mathrm{A}$ of the methane monooxygenase from Methylococcus capsulatus (Bath). The Journal of Biological Chemistry 259(1), 53-59. 